\title{
BEEF SALT-SOLUBLE PROTEINS AND SEAWEED (Eucheuma cottonii) FLOUR INTERACTIONS TO THE QUALITY OF HEAT- INDUCED GEL MATRIX DEVELOPMENT
}

\author{
Aris Sri Widati ${ }^{1)}$, Djalal Rosyidi ${ }^{2),}$, Lilik Eka Radiati ${ }^{2)}$, Happy Nursyam ${ }^{3)}$ \\ ${ }^{1)}$ Postgraduate Student, Faculty of Animal Science, Universitas Brawijaya, Jl. Veteran, Ketawanggede, Kec. \\ Lowokwaru, Kota Malang, Jawa Timur Indonesia 65145 \\ ${ }^{2)}$ Lecturer of Animal Product Technology Department, Faculty of Animal Science, Universitas Brawijaya, Jl. \\ Veteran, Ketawanggede, Kec. Lowokwaru, Kota Malang, Jawa Timur Indonesia 65145 \\ 3) Lecturer of Faculty of Fisheries and Marine Science, Universitas Brawijaya, Jl. Veteran, Ketawanggede, Kec. \\ Lowokwaru, Kota Malang, Jawa Timur Indonesia 65145 \\ *Email: djalal_tht@ub.ac.id
}

Submitted 22 May 2020; Accepted 11 June 2020

\begin{abstract}
The objective of this study was to observe the interactions between salt-soluble proteins from beef and seaweed (Eucheuma cottonii) flour and its effect to the quality of the produced protein gel. The study was conducted as experimental research with two factorials completely randomized design. The effect of different $\mathrm{NaCl}(2.0 \% ; 2.5 \% ; 3.0 \%$; and 3.5\%) and Eucheuma cottonii flour $(5 \% ; 10 \%$; and $15 \%)$ concentrations was observed to the physical and proximate quality of the protein gel matrix. The observed gel quality variables include $\mathrm{pH}$, gel strength, color $\left(\mathrm{L}, \mathrm{a}^{*}\right.$, and $\left.\mathrm{b}^{*}\right)$, moisture, protein, and fat content. The gel was gelatinized at $90^{\circ} \mathrm{C}$ for 20 min and cooled down at $4^{\circ} \mathrm{C}$ for $12 \mathrm{~h}$. The results showed that there was no interaction effect found on all of observed variables. However, a highly significant effect $(\mathrm{P}<0.01)$ was found on the ash content with different salt concentrations, while different Eucheuma cottonii flour concentrations improved the gel strength $(\mathrm{P}<0.01)$ and significantly gave darker $(\mathrm{P}<0.01)$ color. The effect of Eucheuma cottonii flour on the physicochemical properties of the gel was concentration dependent. Therefore, this study concludes that Eucheuma cottonii flour showed a potential as binding or filling agent to form strong gel matrix in processed meat products.
\end{abstract}

Keywords: Binder; Eucheuma cottonii; gelatinization; gel strength; myofibrillar protein 


\section{INTRODUCTION}

Beef contains around 16 to $22 \%$ protein consisting of $11.5 \%$ myofibril, $5.5 \%$ sarcoplasmic, and 3\% stromal protein (Soeparno, 2009). The main components of myofibril protein are myosin and actin, which both works on gelation as well as control the viscoelasticity of the formed protein gel (Purnomo, 2012). The myosin and actin extraction of beef is affected by several factors, such as salt concentration, $\mathrm{pH}$, and non-protein polymers (Sun et al., 2011; Sun dan Holley, 2011).

The salt myofibril proteins extraction is known to be affected by salt concentration, with the common extraction was done with salt solution at $0.3 \mathrm{M}$ or higher. The addition of salt during meatbased food production would extract the salt soluble protein from meat (myosin and actin), and increase the meat binding capacity, yield, and juiciness (Purnomo, 2012). The common salt additions on meatballs are at around $2.5 \%$ to $3 \%$ of the total meat weight, but research by Rahardiyan (2004) and Wibowo (2014) showed minimum salt additions, that are $1.6 \%$ and $2.5 \%$ of the meat weight, respectively. Moreover, research by Keever (2011) that used varied salt concentrations $(0.5 \%$ to $3.5 \%)$ showed that the highest extracted protein was found on $3.5 \%$ salt addition.

The increased myofibril extraction is expected to improve the meat-based food texture due to its functional properties. The functional properties of protein are defined as the properties of protein which could affect the food characteristics, whether during processing, storing, and consumption. Gelation is one of the functional properties of myofibril protein

*Corresponding author:

Djalal Rosyidi

Email: djalal_tht@ub.ac.id

Lecturer of Animal Product Technology Department, Faculty of Animal Science, Universitas Brawijaya, Jl. Veteran, Ketawanggede, Kec. Lowokwaru, Kota Malang, Jawa Timur Indonesia 65145 that is important for the food industry and has been widely applied on restructured meat products. The protein gelation occurs by utilizing the protein interactions such as sulfide bonds between actin-myosin or myosin-myosin. Lam and Nickerson (2013) described that the functional properties of protein are caused by the protein interaction with other compounds, which then affect the food application, quality and consumer's acceptability. Seaweed (Eucheuma cottonii) is categorized as red seaweed (Rodhopychae) that contained $\kappa$ carrageenan which applied on food products to improve the gel strength due to its stabilizing, emulsifying and gel forming properties (MacArtain et al., 2007). The seaweed is also commonly used as filling agent to stabilize the compact texture of meat products (Campo et al., 2009).

In meatballs processing, the added carrageenan from Eucheuma cottonii would improve the dietary fiber content as well as improve the water-holding capacity which then increase the yields as well (Kurniawan et al., 2012). The gelation property of saltsoluble protein could be increased by the addition of Eucheuma cottonii flour as due to its carrageenan content. The protein and carrageenan would interact and formed protein gel with better viscosity. In this study, we observe the effect of different $\mathrm{NaCl}$ and Eucheuma cottonii flour concentrations to the physical and proximate quality of the formed gel protein.

\section{MATERIALS AND METHODS}

\section{Materials}

The materials used in this study are salt-soluble protein gel fraction (myofibril protein) and Eucheuma cottonii flour. The chemicals used for analysis include $\mathrm{H}_{2} \mathrm{SO}_{4}$,

\section{How to cite:}

Widati, A.S., Rosyidi, D., Radiati, L. E., \& Nursyam, H. (2020). Beef Salt-Soluble Proteins and Seaweed (Eucheuma cottonii) Flour Interactions to the Quality of Heat-Induced Gel Matrix Development. Jurnal Ilmu dan Teknologi Hasil Ternak, 15 (2), 61-68 
$45 \% \mathrm{NaOH}, 3 \%$ boric acid, $0.1 \mathrm{~N} \mathrm{HCl}$, methyl orange, PP indicator, petroleum ether, buffer $\mathrm{pH} 4$ and 7, phosphate buffer $\left(0.025 \mathrm{M} \mathrm{Na}_{2} \mathrm{HPO}_{4}\right) \mathrm{pH}$ 7, and $\mathrm{NaCl}$.

\section{Experimental design}

The research was conducted in two factorials completely randomized design. The first factor was $\mathrm{NaCl}$ concentrations $(2 \% ; 2.5 \% ; 3 \%$; and $3.5 \%)$, and the second factor was Eucheuma cottonii flour concentrations $(2.5 \% ; 5 \%$; and $7.5 \%)$ based on the beef weight.

\section{Gel production}

The salt-soluble protein was extracted from beef as following Eady et al. (2014) with modification. The beef was firstly weighed and added with cold phosphate buffer with 1:10 ratio (w/v). The sample was then homogenized for $60 \mathrm{~s}$ and $4{ }^{\circ} \mathrm{C}$ centrifuged $7,000 \mathrm{~g}$ for $15 \mathrm{~min}$. The supernatant was then separated from the precipitate and added with $30 \mathrm{~mL} \mathrm{NaCl}$ solution according to the treatments. The obtained supernatant was myofibril protein, then stored in the refrigerator for gel protein production. The gel production was done by following Choi et al. (2011) with modification. As much as $50 \mathrm{~g}$ myofibril protein was placed in $100 \mathrm{~mL}$ Erlenmeyer flask, and added with Eucheuma cottonii flour as according to the treatments. The solution was then stirred at $90^{\circ} \mathrm{C}$ in water bath for 20 min and cooled down to the room temperature before stored in the refrigerator at $4^{\circ} \mathrm{C}$ for $12 \mathrm{~h}$ before analysis.

\section{pH}

As much as $5 \mathrm{~g}$ of the sample was placed on $50 \mathrm{~mL}$ Erlenmeyer flask, added with $20 \mathrm{~mL}$ distilled water and then homogenized. The sample $\mathrm{pH}$ was measured using a $\mathrm{pH}$ meter, with each sample was measured twice.

\section{Gel strength}

The gel strength measurement was done by using tensile strength texture analyzer (Stable Micro Systems). The initial measurement (pre-test) was done at $1.0 \mathrm{~mm} / \mathrm{s}$, reading measurement at $1.0 \mathrm{~mm} / \mathrm{s}$ and final measurement (post-test) at $10.0 \mathrm{~mm} / \mathrm{s}$, with $25 \%$ pressing distance on probe cylinder P/35 for $60 \mathrm{~s}$ (Schmiele et al., 2015).

\section{Color}

The color measurement was done by using color reader (Minolta) on the inner part of protein gel. Illuminant $\mathrm{C}$ is used to measure the color brightness with $\mathrm{BaCl}_{2}$ as the standard. The color data was presented within stimulus coordinate system (CIE Lab color scale) to measure color $\mathrm{L}, \mathrm{a}^{*}$, and $\mathrm{b}^{*}$.

\section{Proximate analysis}

The proximate analysis was done by following AOAC (2005), which consisted of water, protein, fat, carbohydrate, and ash content measurement.

\section{Data analysis}

All of the data were analyzed using two-way analysis of variance (ANOVA), and followed with Duncan's test to determine the differences among mean values at $\mathrm{P}<0.05$.

\section{RESULTS AND DISCUSSIONS}

\section{Physical characteristics}

The analysis of variance showed that the interaction of $\mathrm{NaCl}$ and Eucheuma cottonii flour at all research treatments did not give significant effect to the $\mathrm{pH}$, gel strength, color $\left(\mathrm{L}, \mathrm{a}^{*}\right.$, and $\left.\mathrm{b}^{*}\right)$ of the gel protein. However, the independent Eucheuma cottonii flour treatment showed highly significant effect $(\mathrm{P}<0.01)$ to the $\mathrm{pH}$, gel strength, and color ( $\mathrm{L}, \mathrm{a}^{*}$, and $\mathrm{b}^{*}$ ) of the protein gel. In Table 1, it can be seen that the $\mathrm{pH}$ of beef gel protein with salt $(\mathrm{NaCl})$ and Eucheuma cottonii flour addition was around 6.52 to 6.8. Furthermore, the sole addition of Eucheuma cottonii flour at 7.5\% increased the $\mathrm{pH}$ from 6.56 to 6.8 . The increased $\mathrm{pH}$ was due to the higher $\mathrm{pH}$ of Eucheuma cottonii flour which was at 7.89, while the flour also contained sodium, 
magnesium, silicon, sulfur, chlorine, potassium, calcium which could increase the pH. Research by Erjanan et al. (2017) showed that seaweed (Kappaphycus alvarezii) flour soaked with $\mathrm{KOH}$ and extracted with $\mathrm{KCl}$ solution had the $\mathrm{pH}$ of 7.75 to 8.04 .

The gel strength in this research (Table 2) was at $5.53 \mathrm{~N}$ to $31.8 \mathrm{~N}$. This showed that the addition of Eucheuma cottonii flour could improve the gel strength. Moreover, the research showed higher addition of Eucheuma cottonii flour results in higher gel strength as well. This is caused by the $\kappa$-carrageenan contained in the Eucheuma cottonii flour that could form strong gel. Myosin and actin are parts of myofibril protein that play an important role to form three dimensional matrix during processing which affect the texture of the final product. Varbeken et al. (2005) added that the addition of $\kappa$-carrageenan at $2 \%$ on the salt-dissolved protein of chicken meat could improve the gel strength and WHC of the produced gel protein. The lightness color of gel protein in this study was at 28.13 to 34.17 (Table 3). The results showed that the addition of Eucheuma cottonii flour decrease the lightness color of gel protein. The decrease in lightness is caused by the brownish color of the formed gel. The result is in accordance to the finding by Huang and Yang (2019) that showed seaweed (Eucheuma cottonii) flour produced brownish to reddish color. Furthermore, the redness color $\left(\mathrm{a}^{*}\right)$ was increased along with increased Eucheuma cottonii flour concentration. The lowest $\mathrm{a}^{*}$ color (8.08) was found on $2.5 \%$ Eucheuma cottonii flour addition, while the highest was found on $7.5 \%$ addition (Table 4 ). The yellowness color (b*) also showed similar results (Table 5). The obtained $b^{*}$ color in this research was around 8.07 to 10.87 , which is caused by the brownish colour of the Eucheuma cottonii flour.

Table 1. pH of the salt-soluble gel protein added with Eucheuma cottonii flour

\begin{tabular}{ccccc}
\hline \multirow{2}{*}{$\mathrm{NaCl}(\%)$} & \multicolumn{3}{c}{ Eucheuma cottonii flour } & \multirow{2}{*}{ Mean value } \\
\cline { 2 - 4 } & $2.5 \%$ & $5 \%$ & $7.5 \%$ & \\
\hline 2 & $6.52 \pm 0.08$ & $6.68 \pm 0.12$ & $6.78 \pm 0.06$ & $6.66 \pm 0.14$ \\
3.5 & $6.55 \pm 0.07$ & $6.71 \pm 0.01$ & $6.79 \pm 0.05$ & $6.68 \pm 0.11$ \\
3.5 & $6.56 \pm 0.07$ & $6.71 \pm 0.02$ & $6.82 \pm 0.01$ & $6.70 \pm 0.12$ \\
Mean value & $6.62 \pm 0.01$ & $6.68 \pm 0.03$ & $6.80 \pm 0.01$ & $6.70 \pm 0.08$ \\
\hline
\end{tabular}

Description: Different superscripts on the same column indicate highly significant differences $(\mathrm{P}<0.01)$

Table 2. Gel strength of salt-soluble gel protein added with Eucheuma cottonii flour

\begin{tabular}{crccc}
\hline \multirow{2}{*}{$\mathrm{NaCl}(\%)$} & \multicolumn{3}{c}{ Eucheuma cottonii flour } & \multirow{2}{*}{ Mean value } \\
\cline { 2 - 4 } & $2.5 \%$ & $5 \%$ & $7.5 \%$ & \\
\hline 2 & $5.53 \pm 0.58$ & $16.70 \pm 1.10$ & $28.15 \pm 1.48$ & $15.38 \pm 9.47$ \\
3.5 & $5.27 \pm 0.15$ & $17.80 \pm 1.01$ & $31.83 \pm 1.57$ & $18.30 \pm 11.55$ \\
3.5 & $5.80 \pm 0.20$ & $18.53 \pm 2.11$ & $30.73 \pm 3.06$ & $18.36 \pm 10.96$ \\
Mean value & $5.60 \pm 0.20$ & $18.07 \pm 1.86$ & $31.80 \pm 1.00$ & $18.49 \pm 11.40$ \\
\hline
\end{tabular}

Description: Different superscripts on the same column indicate highly significant differences $(\mathrm{P}<0.01)$

\section{Chemical characteristics}

In this study, the addition of Eucheuma cottonii flour significantly $(\mathrm{P}<0.01)$ decreased the water content of the gel protein, which reduced from $95.67 \%$ to $91.32 \%$ (Table 6) after added with $7.5 \%$ Eucheuma cottonii flour. Eucheuma cottonii flour had low water content (12.99\% \pm 1.46$)$, 
but had high dry matter content which would alter the water into gel protein. Furthermore, the addition of Eucheuma cottonii flour significantly $(\mathrm{P}<0.01)$ increased the protein content, from 0.18 to $0.37 \%$ (Table 7 ). The condition is due to the higher protein content in Eucheuma cottonii flour $(2.90 \% \pm 0.05)$ compared with myofibril solution extract ( 0.030 to $0.034 \mu \mathrm{l} / \mathrm{ml}$ or 0.003 to $0.0034 \%$ ). In Table 8 , it can be seen that the addition of $\mathrm{NaCl}$ and Eucheuma cottonii flour significantly $(\mathrm{P}<0.01)$ increased the ash content.
The lowest ash content (1.93\%) was found on $2 \% \mathrm{NaCl}$ concentration, while the highest $(2.14 \%)$ was found on $3.5 \% \mathrm{NaCl}$ concentration. The result is caused by the condition that $\mathrm{NaCl}$ would be included as ash during analysis. In addition, the Eucheuma cottonii flour also contained several minerals, such as natrium, magnesium, sulfur, chloride, potassium, and calcium that will increase the ash content. The interaction of $\mathrm{NaCl}$ and Eucheuma cottonii flour did not give significant effect to the fat content (Table 9).

Table 3. Lightness colour (L) of salt-soluble gel protein added with Eucheuma cottonii flour

\begin{tabular}{ccccc}
\hline \multirow{2}{*}{$\mathrm{NaCl}(\%)$} & \multicolumn{3}{c}{ Eucheuma cottonii flour } & \multirow{2}{*}{ Mean value } \\
\cline { 2 - 4 } & $2.5 \%$ & $5 \%$ & $7.5 \%$ & \\
\hline 2 & $34.17 \pm 0.95$ & $30.90 \pm 1.05$ & $28.73 \pm 0.95$ & $31.27 \pm 2.49$ \\
2.5 & $31.97 \pm 0.06$ & $31.37 \pm 1.23$ & $29.57 \pm 2.50$ & $30.97 \pm 1.76$ \\
3 & $31.47 \pm 1.37$ & $30.47 \pm 1.37$ & $29.73 \pm 2.65$ & $30.56 \pm 1.80$ \\
3.5 & $32.53 \pm 0.23$ & $30.90 \pm 1.23$ & $28.13 \pm 0.64$ & $30.52 \pm 2.05$ \\
\hline Mean value & $32.53^{\mathrm{c}} \pm 1.28$ & $30.91^{\mathrm{b}} \pm 1.10$ & $29.04^{\mathrm{a}} \pm 1.74$ & \\
\hline
\end{tabular}

Description: Different superscripts on the same column indicate highly significant differences $(\mathrm{P}<0.01)$

Table 4. Redness color (a*) of salt-soluble gel protein added with Eucheuma cottonii flour

\begin{tabular}{clccc}
\hline \multirow{2}{*}{$\mathrm{NaCl}(\%)$} & \multicolumn{3}{c}{ Eucheuma cottonii flour } & \multirow{2}{*}{ Mean value } \\
\cline { 2 - 4 } & $2.5 \%$ & $5 \%$ & $7.5 \%$ & \\
\hline 2 & $7.63 \pm 0.23$ & $9.10 \pm 1.04$ & $10.03 \pm 0.40$ & $8.92 \pm 1.19$ \\
2.5 & $8.27 \pm 0.29$ & $8.93 \pm 0.21$ & $9.83 \pm 0.15$ & $9.01 \pm 0.71$ \\
3 & $8.27 \pm 0.35$ & $8.90 \pm 0.20$ & $9.93 \pm 0.47$ & $9.03 \pm 0.81$ \\
3.5 & $8.13 \pm 0.21$ & $8.80 \pm 0.20$ & $10.33 \pm 0.57$ & $9.09 \pm 1.03$ \\
\hline Mean value & $8.08^{\mathrm{a}} \pm 0.36$ & $8.93^{\mathrm{b} \pm} 0.50$ & $10.03^{\mathrm{c}} \pm 0.41$ & \\
\hline
\end{tabular}

Description: Different superscripts on the same column indicate highly significant differences $(\mathrm{P}<0.01)$

Table 5. Yellowness colour (b*) of salt-soluble gel protein added with Eucheuma cottonii flour

\begin{tabular}{ccccc}
\hline \multirow{2}{*}{$\mathrm{NaCl}(\%)$} & \multicolumn{3}{c}{ Eucheuma cottonii flour } & \multirow{2}{*}{ Mean value } \\
\cline { 2 - 4 } & $2.5 \%$ & $5 \%$ & $7.5 \%$ & \\
\hline 2 & $8.07 \pm 0.42$ & $10.93 \pm 1.40$ & $11.80 \pm 1.10$ & $10.27 \pm 1.92$ \\
2.5 & $8.00 \pm 1.42$ & $9.43 \pm 0.95$ & $11.20 \pm 1.65$ & $9.54 \pm 1.83$ \\
3 & $8.03 \pm 0.45$ & $8.00 \pm 3.48$ & $11.83 \pm 1.12$ & $9.29 \pm 2.65$ \\
3.5 & $7.50 \pm 0.46$ & $9.20 \pm 0.26$ & $10.87 \pm 0.42$ & $9.19 \pm 1.50$ \\
\hline Mean value & $7.90^{\mathrm{a} \pm} 0.73$ & $9.39^{\mathrm{a}} \pm 1.98$ & $11.43^{\mathrm{b} \pm} 1.08$ & \\
\hline
\end{tabular}

Description: Different superscripts on the same column indicate highly significant differences $(\mathrm{P}<0.01)$ 
Table 6. Water content of salt-soluble gel protein added with Eucheuma cottonii flour

\begin{tabular}{ccccc}
\hline \multirow{2}{*}{$\mathrm{NaCl}(\%)$} & \multicolumn{3}{c}{ Eucheuma cottonii flour } & \multirow{2}{*}{ Mean value } \\
\cline { 2 - 4 } & $2.5 \%$ & $5 \%$ & $7.5 \%$ & \\
\hline 2 & $95.79 \pm 0.16$ & $93.58 \pm 0.23$ & $91.39 \pm 0.22$ & $93.59 \pm 1.91$ \\
2.5 & $95.69 \pm 0.08$ & $93.36 \pm 0.57$ & $91.38 \pm 0.17$ & $93.48 \pm 1.89$ \\
3 & $95.63 \pm 0.10$ & $93.34 \pm 0.26$ & $91.30 \pm 0.24$ & $93.42 \pm 1.88$ \\
3.5 & $95.56 \pm 0.04$ & $93.46 \pm 0.34$ & $91.22 \pm 0.08$ & $93.42 \pm 1.89$ \\
\hline Mean value & $95.67^{\mathrm{a}} \pm 0.12$ & $93.44^{\mathrm{b}} \pm 0.34$ & $91.32^{\mathrm{c}} 0.18$ & \\
\hline
\end{tabular}

Description: Different superscripts on the same column indicate highly significant differences $(\mathrm{P}<0.01)$

Table 7. Protein content of salt-soluble gel protein added with Eucheuma cottonii flour

\begin{tabular}{ccccc}
\hline \multirow{2}{*}{$\mathrm{NaCl}(\%)$} & \multicolumn{3}{c}{ Eucheuma cottonii flour } & \multirow{2}{*}{ Mean value } \\
\cline { 2 - 4 } & $2.5 \%$ & $5 \%$ & $7.5 \%$ & \\
\hline 2 & $0.18 \pm 0.01$ & $0.24 \pm 0.11$ & $0.37 \pm 0.00$ & $0.27 \pm 0.10$ \\
2.5 & $0.18 \pm 0.01$ & $0.31 \pm 0.10$ & $0.37 \pm 0.00$ & $0.29 \pm 0.10$ \\
3.5 & $0.18 \pm 0.01$ & $0.35 \pm 0.03$ & $0.37 \pm 0.00$ & $0.30 \pm 0.09$ \\
\hline Mean value & $0.18 \pm 0.00$ & $0.37 \pm 0.00$ & $0.37 \pm 0.00$ & $0.27 \pm 0.10$ \\
\hline
\end{tabular}

Description: Different superscripts on the same column indicate highly significant differences $(\mathrm{P}<0.01)$

Table 8. Ash content of salt-soluble gel protein added with Eucheuma cottonii flour

\begin{tabular}{ccccc}
\hline \multirow{2}{*}{$\mathrm{NaCl}(\%)$} & \multicolumn{3}{c}{ Eucheuma cottonii flour } & \multirow{2}{*}{ Mean value } \\
\cline { 2 - 4 } & $2.5 \%$ & $5 \%$ & $7.5 \%$ & \\
\hline 2 & $1.80 \pm 0.08$ & $1.92 \pm 0.09$ & $2.07 \pm 0.08$ & $1.93^{\mathrm{a}} \pm 0.14$ \\
2.5 & $1.91 \pm 0.17$ & $2.00 \pm 0.05$ & $2.11 \pm 0.06$ & $2.01^{\mathrm{a}} \pm 0.13$ \\
3 & $1.93 \pm 0.04$ & $2.02 \pm 0.08$ & $2.20 \pm 0.03$ & $2.05^{\mathrm{bd}} \pm 0.13$ \\
3.5 & $1.94 \pm 0.03$ & $2.13 \pm 0.13$ & $2.37 \pm 0.15$ & $2.14^{\mathrm{cd}} \pm 0.21$ \\
\hline Mean value & $1.89^{\mathrm{p} \pm} 0.10$ & $2.02^{\mathrm{q} \pm} 0.11$ & $2.19^{\mathrm{r} \pm} 0.14$ & \\
\hline
\end{tabular}

Description: Different superscripts on the same column indicate highly significant differences $(\mathrm{P}<0.01)$

Table 9. Fat content of salt-soluble gel protein added with Eucheuma cottonii flour

\begin{tabular}{crrrr}
\hline \multirow{2}{*}{$\mathrm{NaCl}(\%)$} & $2.5 \%$ & $5 \%$ & $7.5 \%$ & \multirow{2}{*}{ Mean value } \\
\cline { 2 - 4 } & $0.04 \pm 0.02$ & $0.05 \pm 0.02$ & $0.05 \pm 0.02$ & $0.05 \pm 0.01$ \\
2.5 & $0.05 \pm 0.02$ & $0.04 \pm 0.01$ & $0.04 \pm 0.02$ & $0.04 \pm 0.01$ \\
3 & $0.05 \pm 0.03$ & $0.03 \pm 0.00$ & $0.03 \pm 0.02$ & $0.04 \pm 0.02$ \\
3.5 & $0.03 \pm 0.02$ & $0.03 \pm 0.01$ & $0.05 \pm 0.02$ & $0.04 \pm 0.01$ \\
\hline Mean value & $0.04 \pm 0.02$ & $0.04 \pm 0.01$ & $0.04 \pm 0.02$ & \\
\hline
\end{tabular}

Description: Different superscripts on the same column indicate highly significant differences $(\mathrm{P}<0.01)$

The fat content of gel protein found in this study was at $0.53 \% \pm 0.45$. The result is caused by the low-fat content of both saltsoluble protein and the Eucheuma cottonii flour. The carbohydrate content was significantly $(\mathrm{P}<0.01)$ increased with the addition of Eucheuma cottonii flour. The carbohydrate of gel protein was increased from $2.23 \%$ to $6.08 \%$ with the addition of 7.5\% Eucheuma cottonii flour (Table 10). 
The carbohydrate content was measured by subtracting the overall chemical compound with water, protein, fat, and ash content. In this study, we found that the addition of
Eucheuma cottonii flour affected the water, protein, fat, ash, and carbohydrate of the gel protein significantly

Table 10. Carbohydrate content of salt-soluble gel protein added with Eucheuma cottonii flour

\begin{tabular}{crccc}
\hline \multirow{2}{*}{$\mathrm{NaCl}(\%)$} & \multicolumn{3}{c}{ Eucheuma cottonii flour } & \multirow{2}{*}{ Mean value } \\
\cline { 2 - 4 } & $2.5 \%$ & $5 \%$ & $7.5 \%$ & \\
\hline 2 & $2.19 \pm 0.18$ & $4.17 \pm 0.38$ & $6.12 \pm 0.14$ & $4.16 \pm 1.72$ \\
2.5 & $2.17 \pm 0.10$ & $4.29 \pm 0.67$ & $6.09 \pm 0.19$ & $4.18 \pm 1.74$ \\
3 & $2.27 \pm 0.25$ & $4.29 \pm 0.24$ & $6.10 \pm 0.26$ & $4.22 \pm 1.67$ \\
3.5 & $2.29 \pm 0.03$ & $4.01 \pm 0.25$ & $5.99 \pm 0.11$ & $4.10 \pm 1.61$ \\
\hline Mean value & $2.23^{\mathrm{a}} \pm 0.15$ & $4.19^{\mathrm{b}} \pm 0.38$ & $6.08^{\mathrm{c}} \pm 0.16$ & \\
\hline
\end{tabular}

Description: Different superscripts on the same column indicate highly significant differences $(\mathrm{P}<0.01)$

\section{CONCLUSIONS}

The Eucheuma cottonii flour showed the potential to be used as binding or filling agent for restructured meat products. The addition of Eucheuma cottonii flour showed positive effect to the $\mathrm{pH}$, gel strength, protein and ash content as well as redness $\left(a^{*}\right)$ and yellowness $\left(b^{*}\right)$, but showed negative effect to the lightness (L) of the protein gel.

\section{ACKNOWLEDGEMENTS}

Authors would like to thank Directorate of Higher Education, Ministry of Culture and Education Republic of Indonesia for the research fund through postgraduate scholarship program.

\section{REFERENCES}

Abdolghafour, B., \& Saghir, A. (2014). Development in sausage production and practices-A review Sausage Production: Ingredients and Raw. Journal of Meat Science and Technology, 2(3), 40-50.

AOAC. (2005). Official Methods of Analysis (18th ed.). AOAC International.
Campo, V. L., Kawano, D. F., Silva, D. B. da, \& Carvalho, I. (2009). Carrageenans: Biological properties, chemical modifications and structural analysis - A review. Carbohydrate Polymers, 77(2), 167-180. https://doi. org/10.1016/j.carbpol.2009.01.020

Choi, Y.-S., Park, K.-S., Kim, H.-Y., Kim, H.-W., Song, D.-H., Chung, H.-J., Lee, J.-W., \& Kim, C.-J. (2011). Interactions between chicken saltsoluble meat proteins and makgeolli lees fiber in heat-induced gels. Korean Journal for Food Science of Animal Resources, 31(6), 817-826. https://doi .org/10.5851/kosfa.2011.31.6.817

Eady, M., Samuel, D., \& Bowker, B. (2014). Effect of $\mathrm{pH}$ and postmortem aging on protein extraction from broiler breast muscle. Poultry Science, 93(7), 18251833. https://doi.org/10.3382/ps.2013 $-03619$

Erjanan, S., Dotulong, V., \& Montolalu, R. I. (2017). Mutu karaginan dan kekuataan gel dari rumput laut merah Kappaphycus alvarezii. Media Teknologi Hasil Perikanan, 5(2), 3639. https://doi.org/10.35800/mthp.5.2 .2017.14872 
Huang, M., \& Yang, H. (2019). Eucheuma powder as a partial flour replacement and its effect on the properties of sponge cake. LWT, 110, 262-268. https:// doi.org/10.1016/j.lwt.2019.04.087

Keever, B. (2012). Salt Concentration and Species Affects Protein Extractability and Processed Meat Characteristics. University of Illinois at UrbanaChampaign.

Kurniawan, A., Al-Baarri, A., \& Kusrahayu. (2012). Kadar serat kasar, daya ikat air, dan rendemen bakso ayam dengan penambahan keraginan. Aplikasi Teknologi Pangan, 1(2), 23-27.

Lam, R. S. H., \& Nickerson, M. T. (2013). Food proteins: A review on their emulsifying properties using a structure-function approach. Food Chemistry, 141(2), 975-984. https://doi.org/10.1016/j.foodchem.20 13.04.038

MacArtain, P., Gill, C. I. R., Brooks, M., Campbell, R., \& Rowland, I. R. (2007). Nutritional value of edible seaweeds. Nutrition Reviews, 65(12), 535-543. https://doi.org/10.1301/nr. 2007.dec.535-543

Purnomo, H. (2012). Teknologi pengolahan dan pengawetan daging. UB Press.

Rahardiyan, D. (2004). Bakso (Traditional Indonesian Meatballs) Properties with Postmortem Condition and Frozen Storage. Louisiana State University.
Schmiele, M., Nucci Mascarenhas, M. C. C., da Silva Barretto, A. C., \& Rodrigues Pollonio, M. A. (2015). Dietary fiber as fat substitute in emulsified and cooked meat model system. LWT Food Science and Technology, 61(1), 105-111. https://doi.org/10.1016/j.lwt .2014 .11 .037

Soeparno. (2009). Ilmu dan Teknologi Daging (5th ed.). UGM Press.

Sun, J., Li, X., Xu, X., \& Zhou, G. (2011). Influence of various levels of flaxseed gum addition on the water-holding capacities of heat-induced porcine myofibrillar protein. Journal of Food Science, 76(3), C472-C478. https://doi. org/10.1111/j.1750-3841.2011.02094.x

Sun, X. D., \& Holley, R. A. (2011). Factors influencing gel formation by myofibrillar proteins in muscle foods. Comprehensive Reviews in Food Science and Food Safety, 10(1), 3351. https://doi.org/10.1111/j.1541-43 37.2010.00137.x

Verbeken, D., Neirinck, N., Van Der Meeren, P., \& Dewettinck, K. (2005). Influence of $\kappa$-carrageenan on the thermal gelation of salt-soluble meat proteins. Meat Science, 70(1), 161166. https://doi.org/10.1016/j.meatsci. 2004.12.007

Wibowo, S. (2014). 50 Jenis Bakso Yang Sehat dan Enak. Penebar Swadaya. 